\title{
Functioning of a family with a child suffering from cystic fibrosis and short bowel syndrome - case study
}

\author{
Funkcjonowanie rodziny z dzieckiem chorym na mukowiscydozę i zespół krótkiego jelita \\ - opis przypadku

\section{Justyna Świerczyńska ${ }^{1}$ ABDEF , Agnieszka Mazur ${ }^{2}$ ABEF, Izabela Chojnowska-Ćwiąkała ${ }^{1} \mathrm{ABD}$, Agnieszka Podosek ${ }^{1} \mathrm{AF}$}

\author{
${ }^{1}$ Syntonia Mental Health Clinic, Kielce, Poland \\ ${ }^{2}$ Institute of Pedagogy and Psychology, The Jan Kochanowski University in Kielce, Poland
}

\begin{abstract}
This article presents the problem of the functioning of a family with a child suffering from two painful, chronic and incurable diseases - cystic fibrosis and short bowel syndrome. Its aim is to learn about the impact of these diseases on the occurrence and course of mental disorders in a child and on the functioning of the whole family in which such a child is brought up. Like any longterm illness of a child, it has influenced changes in the functioning of the family system. The parents' functioning and the flexibility of the family system conditioned the acceptance of the diagnosis and determined further participation of the family in the treatment process. This article also discusses the risk of unfavorable attitudes of parents towards the child's illnesses, which may contribute to the development of mental disorders in the child patient, as well as in his/her parents or siblings. In the process of treatment and rehabilitation, the necessity for cooperation of medical staff, the patient and his/her parents has been emphasised.
\end{abstract}

Keywords: cystic fibrosis, short bowel syndrome, functioning of the family with a sick child, attitudes towards the disease, a sick child in the family

\section{Streszczenie}

W niniejszym artykule przedstawiono problematykę funkcjonowania rodziny z dzieckiem chorym na dwie dolegliwe, przewlekłe i nieuleczalne choroby - mukowiscydozę i zespół jelita krótkiego. Jego celem jest poznanie wpływu tych chorób na występowanie i przebieg zaburzeń psychicznych u dziecka oraz na funkcjonowanie całej rodziny, w której takie dziecko jest wychowywane. Jak każda długotrwała choroba dziecka, wpłynęła ona na zmiany w funkcjonowaniu systemu rodzinnego. Funkcjonowanie rodziców oraz elastyczność systemu rodzinnego warunkowały przyjęcie diagnozy i wyznaczały dalsze uczestniczenie rodziny w procesie leczenia. W niniejszym artykule omówiono również ryzyko wystąpienia u rodziców niekorzystnych postaw wobec chorób dziecka, które mogą przyczynić się do rozwoju zaburzeń psychicznych zarówno u chorego dziecka, jak i u jego rodziców czy też rodzeństwa. W procesie leczenia i rehabilitacji podkreślono konieczność współpracy personelu medycznego, pacjentki i jej rodziców.

Słowa kluczowe: mukowiscydoza, zespół jelita krótkiego, funkcjonowanie rodziny z chorym dzieckiem, postawy wobec choroby, chore dziecko w rodzinie

\section{Introduction}

Diseases such as cystic fibrosis and short bowel syndrome are chronic, incurable diseases that directly affect personality development, psyche, adopting attitudes and making decisions. Not only do they affect children but also youth and adults. The child suffering from these diseases is particularly exposed to many difficult and new experiences that are for him/her (unlike youth and adults) either very difficult or impossible to manage on their own. These kinds of diseases bring with them both biological and psychological stress. Discomfort caused by the disease is a factor hindering and disrupting the child's normal 
psychological development. The impact of a chronic disease on the functioning of the psyche has become the subject of interest for scientists [1,2]. The disorganization of mental sphere in the course of a chronic somatic illness could become a source of frustration and deprivation of many needs, it could also lead to lowering of one's self-esteem [3]. According to the definition of "chronic disease" proposed by the World Health Organization, it is a disease of long duration and slow progress [4]. One of its forms is cystic fibrosis - CF. It is a multi-system, chronic, metabolic disease, manifesting itself mainly in the digestive and respiratory systems. It is genetically conditioned and incurable $[5,6]$.

A typical complete picture of the disease is made up of the coexistence of chronic sinus-broncho-pulmonary disease, abdominal discomfort and elevated chlorine concentration in sweat [5]. The first symptoms most often appear in early childhood. Cystic fibrosis has a direct impact on the growth of the child, as well as on weight gain. This is due to the improper absorption of fats and proteins that are excreted in the faeces. The consequences of this disease is an increased predisposition to infections and, most importantly, shortening of the life span. Despite proper nutrition, cystic fibrosis leads to malnutrition, inhibition of weight gain or loss of weight in patients [7]. Thus, it impairs normal growth and development [6]. It is estimated that the demand for protein in the above patients oscillates between $120-150 \%$ of the acceptable energy consumption per day. The problem grows when the energy supply does not satisfy the body's needs, especially when it is accompanied by complications and vomiting due to coughing, or chronic respiratory failure [6]. Moreover, reflux oesophagitis, exocrine pancreatic insufficiency, liver and biliary disorders and chronic malaise may occur, which, unfortunately, also results in higher energy consumption. In cystic fibrosis, parenteral nutrition is used very rarely, most often in patients with gastrointestinal damage, for example, with short bowel syndrome, after surgical procedures or in severely undernourished patients e.g. awaiting liver transplantation [7]. In the course of cystic fibrosis, psychiatric disorders may occur, the most frequent of which are depressive syndromes, resignation attitudes, anxiety disorders, and aggressive behaviours in younger children [5]. In the course of the disease, which often requires the involvement of the whole family (i.a. due to the need for long-term daily rehabilitation), a change in attitudes towards a sick child is sometimes seen in the parents - they show greater leniency towards their offspring, they set him/her fewer demands, which could lead to weakening of the child's socialization process [8].

The case is a little different in relation to the short bowel syndrome. The definitions adopted in the literature define the short bowel syndrome as a disorder manifesting itself and occurring i.a. after intestinal resection, due to insufficient length of the small intestine there is an excessive loss of nutrients, fluids and/or electrolytes, as a consequence of which normal body weight cannot be maintained [9]. A passive reaction to these symptoms and no therapeutic actions entail appearance of the signs of chronic dehydration in patients and, ultimately, selective nutrient deficiency $[10,11]$.

The symptoms indicated above arise most often as a result of another intestinal disease or after massive resection of the small intestine during the neonatal period [12]. The consequence of these conditions is the necessity for secondary adaptation of the intestines to work, and the speed of this adaptation depends on various factors and lasts about two years. Repeated assimilation - its regularity and pace - is, however, determined by the level of absorption disorders and thus, the resulting need for parenteral nutrition found after the resection or a disease. Disturbed water and nutrients absorption through the intestines can lead to water and electrolyte deficiencies, and, consequently, to malnutrition and disorders in the proper functioning of individual organs. Therefore, during this period the patient should be provided with permanent medical care, under which the medical staff should remember to monitor the patient's body weight and electrolyte level [12]. The primary issue of medical treatment is to identify people at risk as soon as possible. Treatment in the short bowel syndrome is divided into three important periods:

1. Postoperative period - focuses on the alignment of metabolic and electrolytes disorders.

2. Adaptation period - during this time the patient takes as much food as possible by oral supply.

3. Period of long-term treatment - if the treatment proceeds with difficulties, the main nutrients are administered by parenteral route [10].

All in all, the treatment of short bowel syndrome should be mainly focused on maintaining the proper nutrition state, water-electrolyte and acid-alkaline balance in the patient as well as selecting the appropriate type of nutritional therapy. The best form of nutrition is the enteral route, which speeds up the adaptation of the intestine and its peristalsis, and also stimulates the activity of the entire gastrointestinal tract. However, in the case of some patients, enteral nutrition is impossible due to the lack of appropriate adaptation of the intestine, which means that nutrients must be administered parenterally and long-term [10].

Any long - term, chronic, and especially incurable or very difficult to cure disease of a child determines profound changes in the family system. It generates stress, frustration of family members, creates additional responsibilities, so it usually involves total reorganization of family life [13]. The way parents perceive a child's disease depends on their strategy 
for coping with stress and patterns of response to the requirements and limitations resulting from the disease. According to Pilecka (1995), assimilation to a child's illness by parents is a long-term process and it usually goes in several stages: shock, panic, denial, grief and despair, mourning the loss of health, acceptance and active action. Chronic somatic illness of a child requires the reorganization of the family life. The need to devote oneself to a sick child is activated $[2,14]$.

Proper attitude of the parents towards an incurably and painfully sick child has a significant impact on the positive development process of a child, it also helps with therapy and builds the child's positive motivation to cope with the disease. The parents' acceptance of the child and all his/her problems, which also include physiological imperfections, including illness, is of fundamental importance in this respect. Accepting a child's health state helps parents deal with a sense of guilt and harm. A sick child, feeling the support of the loved ones, knows that he/she can count on them in any situation.

Besides an extremely important supportive attitude from the parents, an attitude of cooperation is essential for the proper functioning of the sick child. When the disease becomes a common problem and a challenge for the parents and the child, the family has a common goal and due to cooperation it is able to achieve better results in terms of the treatment effectiveness. With regard to the children fed parenterally, parental attitudes, especially mothers', as persons most often involved in the process of treatment and rehabilitation of the child, could be considered as a factor determining therapeutic effect and supporting the development of a sick child. Therefore, understanding parental attitudes of mothers of these children seems not only legitimate, but also essential [15]. As a result of the child's chronic somatic illness, in addition to changes in the internal structure of the family, reorganization in its external activity usually follows. A child's illness entails the necessity for changing priorities and life goals, which may result in depression or frustration reactions in the family. Family members often face a decision to limit working time by one parent in order to take care of a sick child [16].

A child's chronic illness could also trigger parents' improper upbringing attitudes. The most frequently developed attitude towards a chronically ill child is over-protection and leniency. Alternatively, an attitude of avoiding or rejecting a child could develop [17]. Parents with an overprotective attitude protect their children from effort, stress and rejection from the people around them. The parents assuming this attitude are excessively focused on the child and they do not set any requirements for him/her, they try to maintain the strongest, almost symbiotic relationship with the child as long as possible and they do not recognize his/her need for autonomy and the development of independence. As a result, parents limit their contact with people around them because they believe that home environment is the only safe place for a sick child. In such a situation a sick child may begin to manipulate the family environment, whereas outside the family setting, he/she is exposed to loss of self-confidence, anxiety reactions in new situations, confusion, which in consequence may lead to passivity, lack of initiative and submissiveness, and thus to delays in the development of social maturity $[18,19,13]$.

If the family model in which a child suffering from cystic fibrosis or short bowel syndrome is brought up turns out to be wrong, it constitutes an additional barrier for him/her to overcome the problem of his/her own illness. The wrong family model has a negative impact on the child as far as shaping in him/her the image of own body, often significantly different from the bodies of his/her peers.

\section{Case Study}

A twelve-year-old female patient with cystic fibrosis and short bowel syndrome, fed parenterally 7 days a week at home, occasionally hospitalized in a pediatric ward, is under the care of mental health counselling due to emotional and social problems. Both diseases were diagnosed in the patient immediately after birth. These diseases were the reason for multiple hospitalizations.

From the interview with the mother, it is known that the patient is from I pregnancy in which the first and second trimester went well. In the last trimester (week 36), fluid in the child's intestines was observed in the ultrasound (USG) examination. The delivery came as a result of $\mathrm{C}$-section due to the newborn's losing pulse during childbirth. The newborn's weight was $2780 \mathrm{~g}$, length $-47 \mathrm{~cm}$, Apgar score - 7. In the fifth minute the newborn was subjected to intubation. In the first day of life, a surgery was performed due to the twisted mesentery and gastrointestinal obstruction. Psychomotor development was within normal limits. Since the age of 9 , the disease has worsened, the patient often vomited (reasons other than the underlying disease were excluded). Vomiting usually appeared in the morning, accompanied by a strong reflux symptom. Recently, consuming meals by the patient has been noticed to become less and less frequent. She has justified it with the feeling of fullness in the stomach. There was also fear of vomiting, symptoms of heartburn and indigestion. The patient has lost $2.5 \mathrm{~kg}$. She avoided eating e.g. fruit and vegetables.

Currently, the patient is in the sixth grade of primary school. Because of chronic illness, since the third grade she has been provided individual schooling. Then the problems appeared in her relationship with the teacher, who joked mockingly about her mom carrying her schoolbag. At present, the girl does not feel good at school, she is isolated from the group, she feels the fear of school because, as she 
claims, she has experienced a lot of negative comments, also from the teacher who said, "there is no cure for your illness, I will not be giving in to you like your mother is".

The patient's family consists of three people. The patient has no siblings. Her parents lived separately for the first five years of the child's life. After the baby was born, the father did not face the problem of the illness and other problems connected with it and moved out for a few years. When the girl was five years old, her mother moved in with the child's father who was living with his parents back then. This situation continues to this day. Most of the time the girl spends with her mother, they sleep together to this day. The girl has learned to manipulate the symptoms of the disease for her own benefit. She spends little time with her father.

The patient's mother feels burdened by the current life situation, she does not accept the girl's illness, she takes the remarks of the staff personally, she feels that she is blamed for failures in her daughter's treatment. She is being treated psychiatrically because of depressive-anxiety disorders. She admits that under pressure of the burden which she experiences she argues with her daughter, she is nervous and not very consistent. In the absence of support from the immediate family, she often has a feeling of helplessness towards the treatment of the girl and problems with her upbringing. During the child's hospitalization, the mother avoided cooperation with the medical staff, at the girl's request she gave permission to limit the consumption of meals orally and by means of parenteral nutrition. She only hooked up the fat-free parenteral nutrition bags out of the ones planned. She made the decision arbitrarily, without consulting the doctor, considering that the remainder was not right.

A psychological evaluation was conducted at the mental health clinic, in which the following diagnostic tools were applied: an interview, behavioural observation and psychological diagnostic methods (State - Trait Anxiety Inventory for Children - STAIC, EAS Temperament questionnaire, Rotter Incomplete Sentence Blank, Braun - Gałkowska Family Drawing Test). The patient together with her mother regularly attended monthly meetings with the psychologist. The patient was not late for the meetings planned in advance, but it happened occasionally that the appointment was cancelled due to the need for the girl's unexpected hospitalization. In the orientation test, the patient showed normal cognitive development. Her personality was characterized by introversion features, in which the girl presented a high level of anxiety. Although the patient was full of anxiety, she did not reveal it outside. The patient showed a strong emotional bond with her mother, with whom she reluctantly parted for the conversation with the psychologist. In turn, during the appointment with a psychologist, the girl often glanced at her mother while answering questions, as if she was seeking a kind of approval for the answers given by her. The patient's anxiety grew particularly when her mother stopped paying attention to her, or did not give any clues to support her in her answers.

The analysis of psychological examinations shows that the girl feels accepted in the family. In relation to her mother, she exhibits a significant emotional bond and in relation to her father she expresses negative emotions as well. At the meetings with the psychologist, when the girl was alone in the office, she became very silent, she lost her audacity, but at the same time she kept eye contact with the interlocutor and even watched him with interest. She communicated rather non-verbally, nodding above all. Even in response to the question of whether she knows why she came to the psychologist, she just nodded. After the first appointment, the most important task for the psychologist was to initiate interaction with the child. This goal was achieved over time, because after a few meetings, the girl spoke more and more, smiled, made decisions about what she wanted to play, what to talk about. Further meetings with the child were aimed firstly at increasing the sense of security and trust, which should result in greater openness. Further goals of the sessions were to lower the level of anxiety in the child, to release accumulated, suppressed feelings and identify the signals coming from the child's body testifying to her emotional state, and respond to them appropriately.

After the therapy, the girl became more open, there were also signs of improvement in communication in relations with others.

In a conversation with the psychologist, the girl said that sometimes she had a bad day, she was sad, groaning, she did not feel like doing anything, she had a headache. Such periods are, in her view, rare and usually associated, for example, with weather change. She confirmed the fear of the hospital, she said she reacted with fear to medical examination, "now I am afraid of USG, but I must stay positive". The patient answered the questions about her disease, "This disease is my whole life, it's hard, not everyone understands it, I have to live with it. A lot depends on me - I must have inhalations, but I also need my mom's, a physiotherapist's, doctors' help; every day I must have inhalations, drainage, pummeling, my mother helps me so much". She spoke eagerly about her parents, she said she loved her parents. When asked who in the family, in her opinion, was closest to her, she indicated her mother "because she is in the hospital with me, she helps me in my illness".

During the latest hospitalization, the girl spent most of her time with her mother, in the ward. In her free time, between the medical procedures she underwent, she did some handicrafts, she sewed felt mascots. She did not make spontaneous contacts with staff or other patients. Because 
she was hooked up to the medical equipment, she was in bed most of the time. Reluctant to cooperate with medical staff, she was anxious, she reacted anxiously to further examinations, she forced her mother to let her disregard the staff's instructions. At the same time, the mother gave the impression that she was subordinating herself to her daughter.

\section{Discussing the Case}

The presented case study of a 12-year-old female patient with chronic somatic diseases - short bowel syndrome and cystic fibrosis - confirms the risk of psychiatric disorders. In the course of cystic fibrosis and short bowel syndrome, the girl suffered increased anxiety about the nature of the disease and the treatment process. In her relationship with the girl, the mother focused mainly on fulfilling her duties related to her daughter's illness as best as she could, neglecting her psychological needs at the same time. Consequently, the patient's mother adopts an ambivalent approach towards her treatment: on the one hand, she wants to fulfill her parental duties as best as possible, while on the other she is not interested in the emotional needs of the child, and, what is more, she feels a high level of tiredness of the whole situation related to the illness. The patient's mother often succumbed to the girl, did not set her clear boundaries. The girl, feeling strong fear and anxiety, learned to force her mother not to make her comply with medical requirements. Both the patient and her mother have learned to divert attention from the treatment, downplay the necessity to use some pharmacological agents and certain other treatments, putting strictly emotional issues such as mental fatigue or frustration over this necessity. Moreover, the strong fear of reflux symptoms and vomiting increased the girl's reluctance to proper oral and parenteral nutrition and intensified control in this regard. Negative experiences associated with eating (frequent vomiting, reflux symptoms) made the girl began to refuse to eat, she lost weight. The patient manipulated her mother, wanting to gain control over food, forced modification of oral and parenteral nutrition (her mother did not give her part of the food, just a fat-free part). Despite the knowledge about the necessity for proper nutrition and the specificity of the child's disease, the mother permitted the reduction of oral and parenteral food.

The girl did not accept the majority of the problems and issues related to her diseases, although she had a very big knowledge of them, and she understood their course and medical treatment. The factor that hampered the treatment was the high level of fear and anxiety that she could not cope with. The mother induced in the girl her own anxious and fearful attitude towards the disease, which intensified the girl's attitude of non-acceptance towards her health.

Due to cystic fibrosis, the patient's life since birth has focused solely on nutrition, she has experienced many negative symptoms of the disease (including gastric reflux, vomiting). Therefore, the patient developed beliefs about the sense of lack of influence and control over her life, as well as the sense of being ill, weaker. The direct factor supporting the development of these beliefs was the accumulation of anxiety and stress associated with the treatment and experiencing negative symptoms of the disease. The patient began to refuse to eat because of the strong fear of vomiting, reflux, etc. Her mother's first reactions were favourable in the sense that she did not want the girl to experience any unpleasant symptoms, so she agreed to her daughter's refusal to take food.

The case of the patient and her family presented above shows the way of the family functioning, where the child suffers from a chronic, painful and incurable or very difficult to cure disease. The described case highlights certain irregularities in the family functioning. Some of those irregularities, such as incorrect parental attitudes (the mother's ambivalent attitude and the father's withdrawn attitude), and the daughter's forcing attitude triggered by them are the most noticeable. Attitudes assumed by the parents are to a large extent the reason for the family malfunctioning. The parents' personality traits, their ways of coping with the experience of the type of difficulties like chronic, painful and incurable disease of the child as well as their behavioural patterns and developed by them family ties have a huge impact on the quality of the family functioning. The patient gave the impression of a fearful, uncertain person, while the mother gave the impression of a person uninterested in cooperation, passive-aggressive, selfcentered and hurt. The mother imposed the way of seeing the family situation and treatment, while the patient, in order to meet the mother's expectations, submitted to her. At the same time, the patient learned to use her mother's ambivalent attitude by manipulating her and forcing her to get the expected benefits.

\section{Summary}

The occurrence of a chronic illness in a child causes that his/her parents face the necessity to implement many adaptive tasks that are not only emotional, but also cognitive. The nature of the disease itself has a significant impact on emotional adaptation [20]. In the course of cognitive adaptation, the parent's beliefs about the nature of the disease, the significance attributed by him/her to various events related to the disease and the assessment of the scope of control are important. Dealing with a chronic disease, which is associated with numerous limitations in the patient's life, could render special difficulty, both emotional and cognitive. This usually affects the possibility of realistic expectations of parents towards the child in the treatment process. 
The child's chronic illness is a serious emotional shock for the family [21]. It is a source of psychological stress and this outlook is shared by the child and his family [22]. Emotional reactions are an inseparable part of the stress relationship. Defensive behaviours are also an integral element of the natural course of a stressful transaction [23]. In relation to a chronic illness of a child, defense mechanisms associated with subconscious distortion of reality are a frequent form of parents' coping with the following problem: long-term and painful illness of a child. However, they cease to perform adaptive functions when they become a dominant, rigidly used mechanism.

Sometimes the parents' despair affected by a child's severe and incurable chronic disease is so deep that for some time they are not capable of rational thinking and acting [24]. However, most parents, after the initial period of emotional imbalance are mobilized and begin to apply optimal and rational ways of care and upbringing. Sometimes, as in the described case, it happens that mothers of sick children are somatically overprotective, succumb to their children in order to reward their suffering [13].

In the presented case, the girl's disease is of a chronic and oppressive nature. Her treatment requires the patient's cooperation with her parents and medical staff. The weight and annoyance of the disease in both the patient and her parents may create a negative attitude to the people around her, doctors and medical staff. Hospitalisations usually trigger strong experiences both in the child and in the parents. The child may then experience feelings of anxiety and fear. During the girl's hospitalisation, the mother's attitude towards medical treatment is noteworthy. The bond between mother and child is full of anxiety and tension, together with the patient the mother diverts attention from the treatment process, does not comply with the medical staff (does not administer food orally, limits the administration of parenteral food, does not perform inhalation). The mother takes the remarks of the medical staff personally, feels offended, does not focus on tasks, but on the sense of her own harm. She thinks she is not a good-enough mother. She presents compensatory caring by accompanying the child during her sleep, which took place in the hospital, too.

In the treatment of a somatic illness, as well as medical interactions and psychological work with the child, psychological care for the whole family plays an important role. In order to achieve the desired changes, modifications should be made in the whole family system: from psychotherapy of parents' spousal relations, through modification of the way of functioning, which allows to look at the child and his/her family holistically, to the use of specialized psychotherapeutic help for the girl and her mother. Besides, social support for the family members can significantly affect the treatment process and its effects.

All in all, it is worth emphasising the importance of getting to know the family system in which a given patient functions and grows up. It is also important to skillfully link the symptom of a given disorder or illness in a child with the family system in which the child functions, as well as to take an interdisciplinary and holistic approach to his/her overall problems. Treatment of the child's symptom only without reference to the family context may turn out to be a longterm, traumatic and ineffective experience not only for the child, but also for the whole family.

\section{Wprowadzenie}

Choroby takie jak mukowiscydoza i zespół jelita krótkiego, to choroby przewlekłe, nieuleczalne, wpływające bezpośrednio na rozwój osobowościowy, psychikę, przyjmowane postawy oraz podejmowane decyzje. Dotykają one nie tylko dzieci ale również młodzież oraz osoby dorosłe. Zapadłe na te choroby dziecko jest szczególnie narażone na wiele trudnych i nowych doświadczeń, które są dla nich (w odróżnieniu od młodzieży i dorosłych), bądź bardzo trudne bądź też niemożliwe do samodzielnego przepracowania. Tego rodzaju choroby przynoszą ze sobą stres, zarówno biologiczny jak i psychologiczny. Dolegliwości spowodowane chorobą są czynnikiem utrudniającym i zakłócającym prawidłowy rozwój psychiczny dziecka. Wpływ choroby przewlekłejnafunkcjonowanie psychikistałsięprzedmiotem zainteresowania naukowców [1,2]. Dezorganizacja sfery psychicznej w przebiegu chronicznej choroby somatycznej może stać się źródłem frustracji i deprywacji wielu potrzeb, może również prowadzić do obniżenia poczucia własnej wartości [3]. Zgodnie z definicją "choroby przewlekłej" zaproponowaną przez Światową Organizację Zdrowia, jest to choroba o długim czasie trwania i powolnym postępie [4]. Jedną z jej postaci jest mukowiscydoza (zwłóknienie torbielowate, ang. cystic fibrosis - CF). Jest to choroba wieloukładowa, przewlekła, metaboliczna, manifestująca się głównie w obrębie układu pokarmowego i oddechowego. Jest ona uwarunkowana genetycznie i nieuleczalna [5,6]. Na typowy pełnoobjawowy obraz choroby składa się współwystępowanie przewlekłej choroby zatokowo-oskrzelowo-płucnej, dolegliwości brzusznych i podwyższonego stężenia chloru w pocie [5]. Pierwsze objawy najczęściej pojawiają się we wczesnym dzieciństwie. Mukowiscydoza ma bezpośredni wpływ na wzrost dziecka, jak również na przyrost masy ciała. Wynika to z faktu niewłaściwego przyswajania tłuszczów i białek, które wydalane są z kałem. Następstwem tej choroby jest zwiększona skłonność do zakażeń, a co najważniejsze, skraca długość życia. Mukowsiscydoza, pomimo prawidłowego odżywiania, prowadzi u pacjentów do niedożywienia, prowadzi do zahamowania przyrostu bądź spadku masy ciała [7]. Upośledza więc 
ona prawidłowy wzrost i rozwój [6]. Szacuje się, że zapotrzebowanie na białko u w.w. chorych oscyluje w granicach $120-150 \%$ akceptowanego poboru energii na dobę. Problem narasta, gdy podaż energii nie zaspokaja zapotrzebowania organizmu, zwłaszcza gdy towarzyszą temu powikłania i wymioty wskutek napadu kaszlu, czy przewlekła niewydolność oddechowa [6]. Ponadto mogą wystąpić: refluksowe zapalenie przełyku, zewnątrzwydzielnicza niewydolność trzustki, schorzenia wątroby i dróg żółciowych oraz przewlekłe złe samopoczucie, co niestety również wpływa na większe zużycie energii. W mukowiscydozie żywienie pozajelitowe stosowane jest bardzo rzadko, najczęściej u chorych z uszkodzeniami przewodu pokarmowego, np. z zespołem krótkiego jelita, po zabiegach chirurgicznych lub u ciężko niedożywionych pacjentów oczekujących np. na przeszczep wątroby [7]. W przebiegu mukowiscydozy mogą wystąpić zaburzenia psychiczne, z których najczęściej występującymi są zespoły depresyjne, postawy rezygnacyjne, zaburzenia lękowe, a u dzieci młodszych zachowania agresywne [5]. W czasie trwania choroby, która często wymaga zaangażowania całej rodziny (m.in. w związku z koniecznością długotrwałej, codziennej rehabilitacji), u rodziców obserwuje się nieraz zmianę postaw wobec chorego dziecka - wykazują oni większą pobłażliwość wobec niego, stawiają mu mniej wymagań, co może prowadzić do osłabienia procesu socjalizacji dziecka [8].

Trochę inaczej kwestia przedstawia się $\mathrm{w}$ odniesieniu do zespołu jelita krótkiego. Przyjęte w literaturze definicje określają zespół krótkiego jelita jako schorzenie objawiające się tym, że m.in. po resekcji jelitowej z powodu niewystarczającej długości jelita cienkiego występuje nadmierna utrata składników odżywczych, płynów i/ lub elektrolitów w konsekwencji czego prawidłowa masa ciała nie może zostać utrzymana [9]. Bierna reakcja na te objawy i niepodjęcie działań leczniczych powodują u pacjentów pojawienie się oznak przewlekłego odwodnienia, a ostatecznie selektywnych niedoborów składników odżywczych $[10,11]$.

Wskazane powyżej objawy powstają najczęściej w wyniku innej choroby jelit lub po masywnej resekcji jelita cienkiego w okresie noworodkowym [12]. Następstwem tych stanów jest konieczność wtórnej adaptacji jelit do pracy, zaś szybkość tej adaptacji zależy od różnych czynników i trwa około dwóch lat. Powtórna asymilacja - jej prawidłowość i tempo - jest jednak zdeterminowana zastanym po resekcji lub chorobie poziomem zaburzeń wchłaniania i tym samym wynikającą z niego koniecznością stosowania żywienia pozajelitowego. Zaburzone wchłanianie wody oraz składników odżywczych przez jelita może prowadzić zaś do niedoborów wodno-elektrolitowych, a w konsekwencji do niedożywienia oraz zaburzeń $\mathrm{w}$ prawidłowym funkcjonowaniu poszczególnych narządów. Dlatego też w tym okresie pacjent powinien być otoczony permanentną opieką lekarską, w ramach której personel medyczny powinien pamiętać o monitorowaniu masy ciała pacjenta i poziomu elektrolitów [12]. Fundamentalną kwestią postępowania medycznego jest jak najszybsze rozpoznanie zagrożonych omawianym zespołem osób. Leczenie w zespole krótkiego jelita dzieli się na trzy ważne okresy:

1. Okres pooperacyjny - koncentruje się na wyrównaniu zaburzeń metabolicznych i elektrolitów.

2. Okres adaptacyjny - w tym czasie chory przyjmuje jak najwięcej pokarmów drogą doustną.

3. Okres długotrwałego leczenia - jeśli leczenie przebiega z utrudnieniami, główne składniki odżywcze podawane są drogą pozajelitową [10].

Reasumując, leczenie zespołu krótkiego jelita powinno być $\mathrm{w}$ głównej mierze ukierunkowane na zachowanie prawidłowego stanu odżywiania, równowagi wodno-elektrolitowej i kwasowo-zasadowej organizmu chorego oraz dobranie odpowiedniego rodzaju terapii żywieniowej. Najlepszą formą żywienia jest droga dojelitowa, która przyspiesza adaptację jelita i jego perystaltykę a także pobudza czynność całego przewodu pokarmowego. Jednak w stosunku do części pacjentów żywienie dojelitowe jest - z uwagi na brak stosownej adaptacji jelita - niemożliwe, przez co składniki odżywcze muszą być przez nich długotrwale przyjmowane pozajelitowo [10].

Każda długotrwała, przewlekła, a tym bardziej nieuleczalna lub bardzo trudna do wyleczenia choroba dziecka determinuje gruntowne zmiany w systemie rodzinnym. Wywołuje ona u członków rodziny stres, frustrację, przysparza dodatkowych obowiązków, więc zwykle wymaga reorganizacji życia rodzinnego [13]. Sposób postrzegania choroby dziecka przez rodziców zależy od ich strategii radzenia sobie ze stresem oraz wzorców reagowania na wymagania i ograniczenia wynikające z choroby. Według Pileckiej (1995), asymilowanie do choroby dziecka przez rodziców jest procesem długotrwałym i zazwyczaj przebiega w kilku etapach: szoku, paniki, zaprzeczania, żalu i rozpaczy, opłakiwania utraty zdrowia, akceptacji i aktywnego działania. Zapadnięcie przez dziecko na przewlekłą chorobę somatyczną doprowadza do przemian w życiu rodzinnym, gdyż aktywizuje się wówczas potrzeba poświęcenia się choremu dziecku $[2,14]$.

Prawidłowa postawa rodziców wobec dziecka nieuleczalnie i dolegliwie chorego ma znaczący wpływ na pozytywny proces rozwoju dziecka, pomaga również prowadzonej terapii i buduje pozytywną motywację dziecka do radzenia sobie $\mathrm{z}$ chorobą. Podstawowe znaczenie ma w tym zakresie akceptacja dziecka przez rodziców ze wszystkimi jego problemami, które obejmują również niedoskonałości fizjologiczne, w tym choroby. Akceptacja stanu zdrowia dziecka pomaga rodzicom w radzeniu sobie z poczuciem winy i krzywdy. Dziecko chore, czując wsparcie 
ze strony najbliższych, wie, że może na nich liczyć w każdej zaistniałej sytuacji.

Poza niezwykle istotną postawą wsparcia ze strony rodziców, niezbędna do prawidłowego funkcjonowania chorego dziecka jest także postawa współdziałania. Kiedy choroba staje się wspólnym problemem i wyzwaniem dla rodziców oraz dziecka, wówczas rodzina ma wspólny cel i dzięki współdziałaniu jest w stanie osiągnąć lepsze rezultaty w zakresie efektywności leczenia. W odniesieniu do dzieci żywionych pozajelitowo, postawy rodzicielskie, szczególnie matek, jako osób najczęściej zaangażowanych w proces leczenia i rehabilitacji dziecka, można uznać za czynnik determinujący efekt terapeutyczny i wspierający rozwój chorego dziecka. Poznanie postaw rodzicielskich matek tych dzieci wydaje się zatem nie tylko zasadne, ale i bardzo istotne [15]. W wyniku przewlekłej choroby somatycznej dziecka, oprócz zmian w wewnętrznej strukturze rodziny, zwykle następuje również reorganizacja w jej aktywności zewnętrznej. Choroba dziecka pociąga za sobą konieczność zmian priorytetów i celów życiowych, wskutek których w rodzinie mogą pojawić się reakcje depresji lub frustracji. Członkowie rodziny często stoją wówczas przed decyzją ograniczenia czasu pracy zawodowej przez jednego rodzica w celu zaopiekowania się chorym dzieckiem [16].

Przewlekła choroba dziecka może też wyzwalać u rodziców nieprawidłowe postawy wychowawcze. Najczęściej pojawiającą się postawą wychowawczą w stosunku do dziecka przewlekle chorego jest nadopiekuńczość i pobłażliwość. Może to być również postawa unikania bądź odrzucenia dziecka [17]. Rodzice o postawie nadopiekuńczej chronią swoje dzieci przed wysiłkiem, stresem, odrzuceniem ze strony otoczenia. Rodzice prezentujący taką postawę nadmiernie koncentrują się na dziecku i nie stawiają mu żadnych wymagań, starają sięoni podtrzymywaćjaknajdłużej silne, niemal symbiotyczne więzi z dzieckiem i nie uznają jego potrzeby samodzielności i rozwijania niezależności. W rezultacie rodzice sami ograniczają kontakty z otoczeniem, mają oni bowiem przekonanie, że jedyne bezpieczne miejsce dla chorego dziecka to dom. W takiej sytuacji chore dziecko może zacząć manipulować otoczeniem rodzinnym, natomiast poza środowiskiem rodzinnym narażone jest ono na utratę poczucia pewności siebie, reakcje lękowe w nowych sytuacjach, zdezorientowanie, co w konsekwencji może prowadzić do pasywności, braku inicjatywy i ustępliwości w środowisku, a więc do opóźnienia w rozwoju dojrzałości społecznej $[18,19,13]$.

Jeżeli model rodziny, w którym wychowuje się dziecko chore na mukowiscydozę czy zespół jelita krótkiego, okaże się niewłaściwy, wówczas stanowi on dla niego dodatkową barierę w przepracowaniu problemu własnej choroby. Niewłaściwy model rodziny wpływa negatywnie na kształtowanie się obrazu własnego ciała u dziecka, często w sposób istotny odróżniającego się od ciał ich rówieśników.

\section{Opis przypadku}

Dwunastoletnia pacjentka $\mathrm{z}$ mukowiscydozą i zespołem krótkiego jelita, żywiona pozajelitowo 7 dni w tygodniu w warunkach domowych, sporadycznie hospitalizowana $\mathrm{w}$ oddziale pediatrycznym, jest pod opieką poradni zdrowia psychicznego z powodu trudności emocjonalno-społecznych. Obie choroby zostały zdiagnozowane u pacjentki zaraz po urodzeniu. Choroby te były przyczyną wielokrotnych hospitalizacji.

Z wywiadu od matki wiadomo, że pacjentka jest z ciąży I, w której trymestr pierwszy i drugi przebiegał prawidłowo. W ostatnim trymestrze ciąży (36 tygodniu) w badaniu ultrasonograficznym (USG) zaobserwowano płyn w jelitach dziecka. Poród nastąpił w wyniku cesarskiego cięcia z powodu zaniku tętna dziecka podczas akcji porodowej. Waga urodzeniowa $2780 \mathrm{~g}$, dł. $47 \mathrm{~cm}$, w skali Apgar uzyskała 7 punktów. W piątej minucie dziecko zostało poddane intubacji. W pierwszej dobie życia przeprowadzono operację z powodu skrętu krezki i niedrożności przewodu pokarmowego. Rozwój psychoruchowy przebiegał w granicach normy. Począwszy od 9 roku życia nastąpiło zaostrzenie choroby, często wymiotowała (wykluczono inne przyczyny niż choroba podstawowa). Wymioty pojawiały się zwykle w godzinach porannych, towarzyszył im silny objaw refluksu. $\mathrm{W}$ ostatnim czasie u pacjentki zauważalne stało się coraz rzadsze spożywanie posiłków. Uzasadniała to uczuciem pełności w żołądku. Pojawiał się również lęk przed wymiotami, objawy zgagi i niestrawności, Pacjentka straciła na wadze 2,5 kg. Unikała jedzenia, np. owoców i warzyw.

Aktualnie pacjentka uczęszcza do szóstej klasy szkoły podstawowej. Z powodu przewlekłej choroby od trzeciej klasy jest nauczana indywidualnie. Pojawiły się wtedy w klasie problemy w relacji z nauczycielką, która przedmiotem żartu uczyniła sobie pomoc mamy noszącej jej plecak. Obecnie w szkole dziewczynka nie czuje się dobrze, jest wyizolowana z grupy, czuje lęk przed szkołą, gdyż - jak twierdzi - doświadczyła tam dużo negatywnych komentarzy, również ze strony nauczyciela: „na twoją chorobę nie ma lekarstwa, ja nie będę ustępowała ci jak matka”.

Rodzina pacjentki składa się z trzech osób. Pacjentka nie ma rodzeństwa. Przez pierwsze pięć lat życia dziecka rodzice mieszkali osobno. Ojciec po urodzeniu się dziecka nie stawił czoła problemowi choroby oraz innym problemom z nią związanym i na kilka lat wyprowadził się. Gdy dziewczynka miała pięć lat, matka przeprowadziła się do ojca dziecka , który zamieszkiwał w tym czasie u swoich rodziców. Taki stan trwa do dnia dzisiejszego. Większą część czasu dziewczynka spędza z matką, do dnia dzisiejszego wspólnie śpią. Dziewczynka nauczyła się manipulować objawami choroby dla uzyskania własnych korzyści. Z ojcem spędza mało czasu.

Matka pacjentki czuje się obciążona aktualną sytuacją życiową, nie akceptuje choroby dziewczynki, 
uwagi personelu odbiera ksobnie, ma wrażenie, że jest obwiniana o niepowodzenia w leczeniu córki. Sama leczy się psychiatrycznie z powodu zaburzeń depresyjno - lękowych. Przyznaje, że w sytuacji doświadczanego obciążenia kłóci się z córką, jest przy tym nerwowa, mało konsekwentna. Przy braku wsparcia ze strony najbliższej rodziny często ma poczucie bezradności wobec procesu leczenia dziewczynki oraz problemów wychowawczych. Podczas hospitalizacji dziecka matka unikała współpracy z personelem medycznym, na prośbę dziewczynki dawała przyzwolenie na ograniczenie spożywanych posiłków zarówno doustnych, jak i poprzez podłączanie worków żywienia pozajelitowego. Z planowanych do przetoczenia worków żywienia pozajelitowego, podłączała wyłącznie część beztłuszczową. Bez konsultacji z lekarzem, samowolnie podjęła taką decyzję, uznając, że pozostała ich część jest nieprawidłowa.

W poradni zdrowia psychicznego przeprowadzono badanie psychologiczne, w którym zastosowano następujące narzędzia diagnostyczne: wywiad, obserwację zachowania oraz psychologiczne metody diagnostyczne (Inwentarz Stanu i Cechy Lęku dla Dzieci - STAIC, Kwestionariusz temperamentu - EAS, Test Zdań Niedokończonych Rottera TZN, Rysunek Rodziny - Braun-Gałkowskiej). Na spotkania z psychologiem pacjentka zgłaszała się razem ze swoją matką systematycznie w każdym miesiącu. Na spotkania umawiane ze stosownym wyprzedzeniem, pacjentka nie spóźniała, zdarzało się jednak, że wizyta była odwoływana z uwagi na konieczność nagłej hospitalizacji dziewczynki. Pacjentka w badaniu orientacyjnym wykazywała prawidłowy rozwój poznawczy. W osobowości widoczne były cechy introwersji, w ramach których dziewczynka prezentowała wysoki poziom lęku. Pacjentka była pełna niepokoju, choć nie ujawniała go na zewnątrz. Pacjentka wykazywała silne przywiązanie emocjonalne do matki, z którą się niechętnie rozstawała na czas rozmowy $\mathrm{z}$ psychologiem. Z kolei podczas wizyty u psychologa dziewczynka często zerkała na swoją matkę odpowiadając na pytania, tak jakby szukała $\mathrm{u}$ niej swoistej aprobaty dla udzielanych odpowiedzi. Niepokój u pacjentki narastał szczególnie wówczas, gdy matka przestawała zwracać na nią uwagę, bądź nie udzielała wskazówek wspierających ją w odpowiedziach.

Z analizy badań psychologicznych wynika, że dziewczynka czuje się akceptowana $\mathrm{w}$ rodzinie. W stosunku do swojej matki przejawia znaczne przywiązanie emocjonalne, zaś do swojego ojca wyraża również emocje negatywne. Na spotkaniach z psychologiem, gdy dziewczynka była sama w gabinecie, stawała się bardzo małomówna, traciła śmiałość, lecz przy tym utrzymywała kontakt wzrokowy z badającym, a wręcz mu się przyglądała. Porozumiewała się raczej niewerbalnie, przede wszystkim kiwając głową. Nawet na pytanie, czy wie, dlaczego przyszła do psychologa, kiwnęła przytakująco głową. Po pierwszym spotkaniu najistotniejszym zadaniem dla psychologa było nawiązanie kontaktu z dzieckiem. Cel ten z czasem został osiągnięty, gdyż po kilku spotkaniach dziewczynka coraz więcej mówiła, uśmiechała się, podejmowała decyzje w co się chce bawić, o czym rozmawiać. Dalsze spotkania z dzieckiem ukierunkowane były po pierwsze na zwiększanie poczucia bezpieczeństwa i zaufania, co w efekcie powinno zaowocować większą jego otwartością. Kolejnymi celami spotkań były: obniżenie poziomu lęku u dziecka, odreagowanie nagromadzonych, tłumionych przez nie uczuć oraz zidentyfikowanie sygnałów płynących z ciała dziecka, świadczących o jego stanie emocjonalnym i odpowiednie reagowanie na nie.

Po terapii dziewczynka stała się bardziej otwarta, zauważalne były również oznaki poprawy komunikacji $\mathrm{w}$ relacjach $\mathrm{z}$ innymi.

W rozmowie z psychologiem dziewczynka podawała, że czasami ma zły dzień, wtedy jest smutna, jęcząca, nic jej się nie chce, boli ją głowa. Takie okresy występowały - jej zdaniem - rzadko i zwykle były związane np. ze zmianą pogody. Potwierdzała lęk przed szpitalem, podawała, że reaguje lękiem na badania - „teraz boję się USG, ale jestem dobrej myśli”. Na pytania dotyczące choroby pacjentka odpowiadała: „Ta choroba to całe życie, jest ciężko, nie wszyscy to rozumieją, ja muszę z tym żyć. Wiele zależy ode mnie - muszę robić inhalacje, ale również potrzebuję pomocy mamy, rehabilitanta, lekarzy; codziennie muszę robić inhalacje, drenaż, klepanie, bardzo mi pomaga w tym mama". O rodzicach wypowiadała się chętnie, mówiła, że kocha rodziców. Pytana o to, kto w rodzinie - według niej jest jej najbliższy, odpowiadała, że matka „bo jest ze mną w szpitalu, pomaga mi w chorobie".

Podczas ostatniej hospitalizacji na oddziale dziewczynka większą część czasu spędzała z matką. W czasie wolnym, między stosowanymi procedurami medycznymi, zajmowała się pracami ręcznymi, wyszywała maskotki z filcu. Nie nawiązywała spontanicznych kontaktów z personelem i innymi pacjentami. Z uwagi na podłączenie do aparatury medycznej większość czasu przebywała w łóżku. Niechętnie współpracowała z personelem medycznym, była lękowa, reagowała niepokojem na kolejne badania, wymuszała na matce przyzwolenie na niestosowanie się do zaleceń. Matka sprawiała przy tym wrażenie, że podporządkowuje się córce.

\section{Omówienie przypadku}

Przedstawiony opis przypadku 12 - letniej pacjentki z przewlekłymi chorobami somatycznymi - zespołem jelita krótkiego i mukowiscydozą potwierdza ryzyko wystąpienia zaburzeń w sferze psychicznej. W przebiegu mukowiscydozy i zespołu jelita krótkiego u dziewczynki wystąpił nasilony lęk dotyczący istoty choroby i procesu leczenia. Matka w relacji z dziewczynką koncentrowała się głównie na tym, aby możliwie jak najlepiej wypełnić swoje obowiązki 
związane z chorobą córki, zaniedbując jej potrzeby psychologiczne. Matka pacjentki przyjmuje zatem postawę ambiwalentną wobec jej leczenia: z jednej strony chce jak najlepiej wypełniać swoje rodzicielskie obowiązki, zaś z drugiej nie jest zainteresowana emocjonalnymi potrzebami dziecka, co więcej - odczuwa wysoki poziom zmęczenia całą sytuacją związaną z jego chorobami. Matka pacjentki często ulegała dziewczynce, nie stawiała jej wyraźnych granic. Dziewczynka, odczuwając silny lęk i niepokój, nauczyła się wymuszać na matce niestosowanie się do wymagań medycznych. Zarówno pacjentka, jak i jej matka nauczyły się odwracać uwagę od leczenia, bagatelizować konieczność stosowania niektórych środków farmakologicznych oraz pewnych innych sposobów leczenia, stawiając ponad tą konieczność kwestie emocjonalne, takie jak zmęczenie psychiczne czy też frustrację.

Ponadto silny lęk przed wystąpieniem objawów refluksu, wymiotów wzmacniał niechęć dziewczynki do prawidłowego odżywiania doustnego i pozajelitowego oraz nasilał kontrolę w tym zakresie. Negatywne doświadczenia związane z jedzeniem (częste wymioty, objawy refluksu) spowodowały, że dziewczynka zaczęła odmawiać jedzenia, straciła na wadze. Pacjentka manipulowała matką chcąc uzyskać kontrolę nad jedzeniem, wymuszała modyfikację odżywiania doustnego oraz pozajelitowego (matka nie podawała części jedzenia, podawała tylko część beztłuszczową). Matka, pomimo wiedzy na temat konieczności prawidłowego odżywiania i specyfiki choroby dziecka, przyzwalała na redukcję jedzenia doustnego i pozajelitowego.

Dziewczynka nie akceptowała większości problemów i kwestii związanych z jej chorobami, chociaż miała bardzo bogatą wiedzę na ich temat, rozumiała ich przebieg i postępowanie medyczne. Czynnikiem, który utrudniał leczenie, był wysoki poziom lęku i niepokoju, z którym nie potrafiła sobie radzić. Matka indukowała przy tym dziewczynce własną, pełną niepokoju i obaw postawę wobec choroby, co nasilało u dziewczynki postawę braku akceptacji dla swojego stanu zdrowia.

W związku z mukowiscydozą życie pacjentki od urodzenia koncentrowało się wyłącznie na odżywianiu, doświadczała ona wielu negatywnych objawów choroby (m. in. refluks żołądka, wymioty). W związku z tym pacjentka wytworzyła przekonania dotyczące poczucia braku wpływu i kontroli na swoje życie, a także poczucia bycia chorą, słabszą. Bezpośrednim czynnikiem sprzyjającym rozwojowi tych przekonań było $\mathrm{w}$ tym przypadku nagromadzenie lęku i stresu związanego z leczeniem i doświadczaniem negatywnych objawów choroby. Pacjentka zaczęła odmawiać jedzenia z powodu odczuwania silnego lęku przed wystąpieniem wymiotów, refluksu, etc. Pierwsze reakcje matki, były przychylne $w$ takim sensie, że matka chciała, aby dziewczynka nie doświadczała przykrych objawów, zgadzała się zatem na odmowy przyjmowania jedzenia przez córkę.

Przedstawiony powyżej przypadek pacjentki i jej rodziny wskazuje na sposób funkcjonowania rodziny, w której dziecko choruje na przewlekłą, dolegliwą i nieuleczalną bądź bardzo trudną do wyleczenia chorobę. Opisany przypadek wskazuje na pewne nieprawidłowości w funkcjonowaniu systemu rodzinnego, wśród których nieprawidłowe postawy rodzicielskie (ambiwalentna postawa matki oraz wycofana postawa ojca), oraz spowodowana tym wymuszająca postawa córki są najbardziej zauważalne. Przyjęte postawy rodzicielskie są w dużym stopniu przyczyną nieprawidłowego funkcjonowania rodziny. Cechy osobowości rodziców, ich sposoby radzenia sobie z doświadczaniem tego rodzaju trudności jak przewlekła, dolegliwa i nieuleczalna choroba dziecka a także ich schematy postępowania oraz wykształcone przez nich w rodzinie więzi mają kolosalny wpływ na jakość funkcjonowania takiej rodziny. Pacjentka sprawiała wrażenie osoby zalęknionej, niepewnej, natomiast matka, osoby niezainteresowanej współpracą, bierno - agresywnej, skoncentrowanej na sobie i poczuciu własnej krzywdy. Matka narzucała sposób widzenia sytuacji rodzinnej i leczenia, pacjentka zaś chcąc sprostać oczekiwaniom matki podporządkowywała się jej. Jednocześnie pacjentka nauczyła się wykorzystywać ambiwalentną postawę matki, manipulując nią i wymuszając uzyskanie oczekiwanych korzyści.

\section{Podsumowanie}

W literaturze często podkreśla się psychospołeczny wymiar zaburzeń chronicznych [20]. Występowanie choroby przewlekłej u dziecka sprawia, że jego rodzice stają wobec konieczności realizacji wielu zadań adaptacyjnych, które mają wymiar nie tylko emocjonalny, ale i poznawczy. Charakter samej choroby wywiera istotny wpływ na adaptację emocjonalną. W przebiegu adaptacji poznawczej ważne miejsce zajmują przekonania rodzica dotyczące istoty choroby, znaczenie przypisywane przez niego różnym zdarzeniom związanym z chorobą oraz ocena zakresu posiadanej kontroli. Szczególną trudność, emocjonalną i poznawczą, może sprawiać radzenie sobie z chorobą przewlekłą, która łączy się z licznymi ograniczeniami w życiu pacjenta. Zwykle rzutuje to na możliwości kształtowania się realistycznych oczekiwań rodziców wobec dziecka w procesie leczenia.

Choroba przewlekła dziecka jest poważnym wstrząsem emocjonalnym dla rodziny [21]. Stanowi ona źródło stresu psychologicznego i tak też bywa oceniana przez dziecko i jego rodzinę [22]. Nieodłącznym składnikiem relacji stresowej są reakcje emocjonalne. Integralny element naturalnego przebiegu transakcji stresowej stanowią również zachowania obronne [23]. W odniesieniu do choroby przewlekłej dziecka mechanizmy obronne 
związane z nieświadomym zniekształcaniem rzeczywistości są częstą formą radzenia sobie przez rodziców z problemem takim jak: długotrwała i dolegliwa choroba dziecka. Przestają one jednak pełnić funkcje adaptacyjne wówczas, gdy stają się dominującym, stosowanym w sposób sztywny, mechanizmem.

Czasami rozpacz rodziców dotkniętych ciężką i nieuleczalną chorobą przewlekłą dziecka jest tak duża, że przez pewien czas nie są oni zdolni do racjonalnego myślenia i działania [24]. Jednak większość rodziców, po początkowym okresie zaburzeń równowagi emocjonalnej, mobilizuje się i zaczyna stosować optymalne i racjonalne sposoby opieki i wychowania. Niekiedy - jak w opisanym przypadku - zdarza się, że matki dzieci chorych somatycznie wykazują nadopiekuńczość, ulegają dzieciom w celu wynagrodzenia im doznawanego cierpienia [13].

W prezentowanym przypadku choroba dziewczynki ma charakter przewlekły i uciążliwy. Jej leczenie wymaga współpracy pacjentki z rodzicami i personelem medycznym. Ciężar i dokuczliwość choroby zarówno u pacjentki, jak i u jej rodziców mogą powodować negatywne nastawienie do otoczenia, lekarzy, personelu medycznego. Pobyty w szpitalu zwykle wyzwalają silne przeżycia zarówno w dziecku, jak i w rodzicach. Dziecko może wówczas doświadczać uczucia niepokoju i lęku. Podczas pobytu dziewczynki w szpitalu zwraca uwagę postawa matki wobec leczenia medycznego. Stosunek matki do dziecka jest pełen niepokoju i napięcia, razem z pacjentką odwraca ona uwagę od procesu leczenia, nie stosuje się do wymagań personelu medycznego (nie podaje jedzenia doustnie, ogranicza podawanie jedzenia pozajelitowego, nie wykonuje inhalacji). Na uwagi ze strony personelu medycznego matka reaguje ksobnie, czuje się urażona, nie koncentruje się na zadaniach, tylko na poczuciu własnej krzywdy. Wydaje jej się, że nie jest wystarczająco dobrą matką. Prezentuje ona kompensacyjną opiekuńczość poprzez towarzyszenie dziecku podczas jego snu, co miało miejsce również w szpitalu.

W leczeniu choroby somatycznej obok oddziaływań medycznych i pracy psychologicznej z dzieckiem istotną rolę odgrywa opieka psychologiczna wobec całej rodziny. Aby uzyskać pożądane zmiany, należy przeprowadzić modyfikacje w całym systemie rodzinnym: od psychoterapii relacji małżeńskich rodziców, przez modyfikację sposobu funkcjonowania, która pozwala spojrzeć na dziecko i jego rodzinę w sposób holistyczny, aż po stosowanie specjalistycznej pomocy psychoterapeutycznej wobec dziewczynki i jej matki. Również wsparcie społeczne wobec członków rodziny może znacząco wpłynąć na proces leczenia i jego efekty.

Reasumując: warto podkreślić znaczenie poznania systemu rodzinnego, w jakim dany pacjent funkcjonuje i dorasta. Istotnym jest też umiejętne powiązanie objawu danego zaburzenia lub choroby u dziecka z systemem rodzinnym, w jakim ono funkcjonuje a także interdyscyplinarne i holistyczne podejście do całokształtu jego problemów. Leczenie samego objawu u dziecka, bez odniesienia go do kontekstu rodzinnego, może okazać się bowiem długotrwałym, traumatycznym i mało skutecznym przeżyciem nie tylko dla niego, ale również dla całej jego rodziny.

\section{Conflict of interest}

The authors have declared no conflict of interest.

\section{References}

1. Twarduś K. Choroba przewlekła i niepełnosprawność jako sytuacje trudne w życiu dziecka i jego rodziny. In: Krzeczowska B, Perek M, Cepuch G (eds.): Modele pielęgnowania dziecka przewlekle chorego. Wydawnictwo Lekarskie PZWL, Warszawa 2011: 25-34.

2. Mess E, Kulpa M, Jerczak B et al. Postawy rodzicielskie wobec dzieci z chorobą nowotworową i alergiczną a ból odczuwany przez dzieci. Psychoonkologia 2014, 4: 153-159.

3. Grabińska E, Efta D, Barczykowska E, Kurylak A. Postawy dzieci chorych na mukowiscydozę i astmę oskrzelową wobec własnej choroby. Pielęgniarstwo XXI wieku 2011: 18-22.

4. World Health Organization: Manual of the International Statistical Classification of the Diseases, and Related Health Problems (wyd. 10, 1). Geneva, WHO, 1992.

5. Mazurek H (red.). Mukowiscydoza. Wydawnictwo Medical Tribune Polska. Warszawa 2012.

6. Thomson A. H., Harris A. Mukowiscydoza, przyczyny, badania, leczenie. Wydawnictwo lekarskie PZWL, Warszawa, 2013.

7. Pogorzelski A. Zajęcie układu pokarmowego. W: Mazurek H (red): Mukowiscydoza. Wydawnictwo Medical Tribune Polska. Warszawa, 2012.

8. Wolańczyk T. Zaburzenia psychiczne w chorobach somatycznych. In: Namysłowska I (ed.): Psychiatria dzieci i młodzieży. Wydawnictwo Lekarskie PZWL, Warszawa 2005: 382-405.

9. Dec M, Lachowska - Kotowska P, Prystupa A, Bartoszek E, Mosiewicz J. Niedokrwistość w przebiegu zespołu krótkiego jelita - opis przypadku. Family Medicine and Primary Care Review, 2012, 14, 2: 306-308.

10. Braszczyńska J. Zespół ponownego odżywienia w przebiegu zespołu krótkiego jelita. Postępy Żywienia Klinicznego 2015, nr 3; https://pzk.wydawnictwo-scientifica.pl/artykuly/113-nr-32015-wrzesien/303-zespol-ponownego-odzywienia-w-przebieguzespolu-krotkiego-jelita/.

11. Vanderhoof J. Short bowel syndrome. Revista de Gastroenterología de México 2010; Supl.2(75): 271-273.

12. Książyk J, Sibilska M, Banaś E, Popińska K. Zespół krótkiego jelita jako konsekwencja chirurgii przewodu pokarmowego. Standardy medyczne/Pediatria, 2010, T. 7: 947-952.

13. Kędziora S. Wpływ przewlekłej choroby dziecka na funkcjonowanie rodziny. Nauczyciel i Szkoła 2007; nr 3-4 (36-37): 57-66.

14. Szczepanik R. Rodzina wobec chorego dziecka. Problemy Opiekuńczo-Wychowawcze 2000; nr 8: 35-38.

15. Cepuch G, Perek M, Foryś Z, Seń M. Postawy rodzicielskie matek wobec dzieci żywionych pozajelitowo. In: Seń M, Dębska G (eds.): Zagrożenia zdrowotne wśród dzieci i młodzieży. Wydawnictwo: Krakowskie Towarzystwo Edukacyjne sp. z o.o. - Oficyna Wydawnicza AFM, Kraków 2011; tom 2: 55-66.

16. Makiełło-Jarża G. Problemy psychologiczne rodzin wychowujących dzieci niepełnosprawne i przewlekle chore. In: Smoczyńska M (ed.) Studia z psychologii rozwojowej i psycholingwistyki. Warszawa 
1998.

17. Ziemska M. Postawy rodzicielskie. Państwowe Wydawnictwo Wiedza Powszechna, Warszawa 1973

18. Pilecka W. Dynamika rozwoju psychicznego dzieci chorych na astmę i mukowiscydozę. Kraków 1990.

19. Pilecka W. Choroba przewlekła dziecka, jego rozwój i interakcje - model transakcyjny. In: Chodkiewicz M (ed.): Dziecko niepełnosprawne $\mathrm{w}$ rodzinie. Socjalizacja i rehabilitacja. Wydawnictwo UMCS, Lublin 1995.

20. Bishop G. Psychologia zdrowia. Wydawnictwo Astrum, Wrocław 2000.

21. Kozieł D, Naszydłowska K, Zdziebło K. Rodzina w zdrowiu i chorobie. Małżeństwo i rodzina 2003; nr 2 (6): 35-38.

22. Heszen I. Kliniczna psychologia zdrowia. In: Sęk H (red.): Psychologia kliniczna, t. 2. Wydawnictwo Naukowe PWN Warszawa 2005: 222-243.

23. Makowska H, Poprawa R. Radzenie sobie ze stresem w procesie budowania zdrowia. In: Dolińska-Zygmunt G (ed.): Podstawy psychologii zdrowia. Wydawnictwo Uniwersytetu Wrocławskiego, Wrocław 2001: 71-102.

24. Maciarz A. Psychoemocjonalne i wychowawcze problemy dzieci przewlekle chorych. Kraków 1998.

\section{Corresponence address:}

Justyna Świerczyńska,

Przychodnia Syntonia, ul. Podgórska 20, 25-103 Kielce,

tel.+484134152 57,

fax +48413615302,

e-mail: j_swierczynska@wp.pl

Otrzymano: 13.06.2018

Zrecenzowano:24.06.2018, 25.06.2018

Przyjęto do druku:27.06.2018 